\title{
Rethinking the dimensions and approach of Circular economy from the perspective of developing countries
}

\author{
Sadhana Manthapuri, NIUM, India
}

\begin{abstract}
Developing Nations represents over 60 percentage of Globe. Economic growth of these nations linearly depends on combinations of market externalities, technological progress and gross value addition. Most of these nations were mere supplier of raw materials in the industrial era and still $70 \%$ of Nation's population is dependent on primary sector for livelihood. This new wave of development, Circular Economy is said to create a value addition and trigger the prosperity of these nations by looping the production and supply chain mechanism. Research estimates that up to 85 per cent of opportunities to improve resource productivity lie in developing countries because of existing stage of economic growth. The portrayed illustrations of circular economy will manifest variant in developing nations. This paper focus on examining the applicability of circular economy, its dimensions and approaches for developing nations. The scale of applicability, market externalities, the bygone pillar of social dimension in sustainability etc, were discussed to provide a significant way forward for the concept to be more restorative and sustainable in the context of developing nations.
\end{abstract}

\section{Keywords}

Developing nations, Market externalities, Dimensions, Approach, Circular economy.

\section{Introduction}

\subsection{Background}

Human race reached an era of technical advancement where boundless innovations happen every day. The rise of machines has mechanized the manual production, reducing time taken for production, evoking new trade and production polices. After the industrialization, both the developed and developing nations faced off with environmental and social disbalances. The limitations of economic growth were research upon with conditioned non-economic parameters (Brundtland,1987).

In the classical and neo-classical economics model, economic systems overlooked the interconnections with nature, prospecting the consumption of goods into categories of economic goods and free goods (Mishan 1967; Sullivan 1972). Utility of goods framed on demand and consumer satisfaction. Mushrooming of allied industries sprung up aiding the production process. Negative trade-offs of traditional systems impacted quality of life and environment balance. New concepts of "environment and ecological economics" developed to promote the importance of nature, criticizing the linear "take make dispose" model of industrial production and consumption. Smith (2002) in his research formulated six 
objects of environmental choices (OEC) that would enhance that the economic productivity. The decades there after focused onto optimal utilization of resources.

Though the concept of circular economy (CE) has been in practice by mankind since primeval times, the investigation and prominence of CE gained momentum after 1970's. The new schools of thought that emerged focused on new design principles. Eliminating the concept of waste with reinforcing the renewable resources was propagated under "cradle to cradle" model (William, 2002). Industrial ecology was assessed using new functional models focusing on local ecological constraints, regenerative designs, closed loop flows, nature inspired innovations and natural capitalism aspects. (Stahel,2008; Benyus,1997; Hawken,2000;).

EU was the former nation to experiment various ways to alternate the flows of linear system, followed by china as it was first country to adopt a law to circular economy. CE paves way for economic systems that aim for becoming more sustainable and attain economic development (EMAF,2013). The research from Ellen MacArthur foundation $(2012,2017)$ emphasized that EU alone can yield net material cost saving from USD340 to 630 billion, India can earn an annual benefit of ₹40 lakh crore(US\$ 624 billion) which is about 30\% of exiting GDP just by shifting to CE in three sectors : cities and construction, food and agriculture, and mobility and vehicle manufacturing( EMAF, 2017).

On average out of every 100 research articles that were available on circular economy, 80 of them focused on conceptualizing circular economy and rest 20 focused case studies. Among the conceptualizing papers, various researchers focused on CE principles, limits and models various implementation strategies with limited studies on indicators. The investigation of case studies specified over top-down policy approach from china and bottom up micro-level approach in EU and US. Very limited studies were available on understanding the CE model in developing and under-developed nations.

\subsection{Theming the Circular Economy concept}

Circular economy has got globally recognized for its potential economic benefits only after 2012(EMAF,2012). Driven by sustainable economic agenda, CE has as a concept has diversified approaches with adaptation to in-situ principles. Most of the research regarded CE as concept extension for 3R reduce, reuse and recycle policies (Heshmati,2015; Government of People's Republic of China, 2008; Stahel, 2013;). Development studies considered CE as concept to promote eco-design and ensure a balance between development and environment. The process like green procurement and strategic tools like life cycle assessment became a constructive part for project appraisal. Thus, the traditional system of material input-output linkages seemed with extension of environment and energy input-out linkages (Genovese et al., 2017; Geng et al., 2013).

Circular economy is viewed as the concept to achieve sustainable economic growth as it is aimed at promoting creation of jobs, profit maximization of existing resources and options for new business opportunities. Ellen MacArthur Foundation envisioned CE to establish economic systems of "Regenerate, Share, Optimise, Loop, Virtualise, and Exchange" nature. The CE concept is also perceived as a business role model attaining "stock optimisation" (Stahel, 2013). Many researchers focused on optimising the production-supply chain with focus of individual components such as material sourcing, design, distribution\& sales, consumption and use, collection and disposal, recycle and recovery and remanufacturing are studied at micro scale and stand-alone criteria (Kalmykova et al.,2018). 
Figure 1: Business model of circular economy

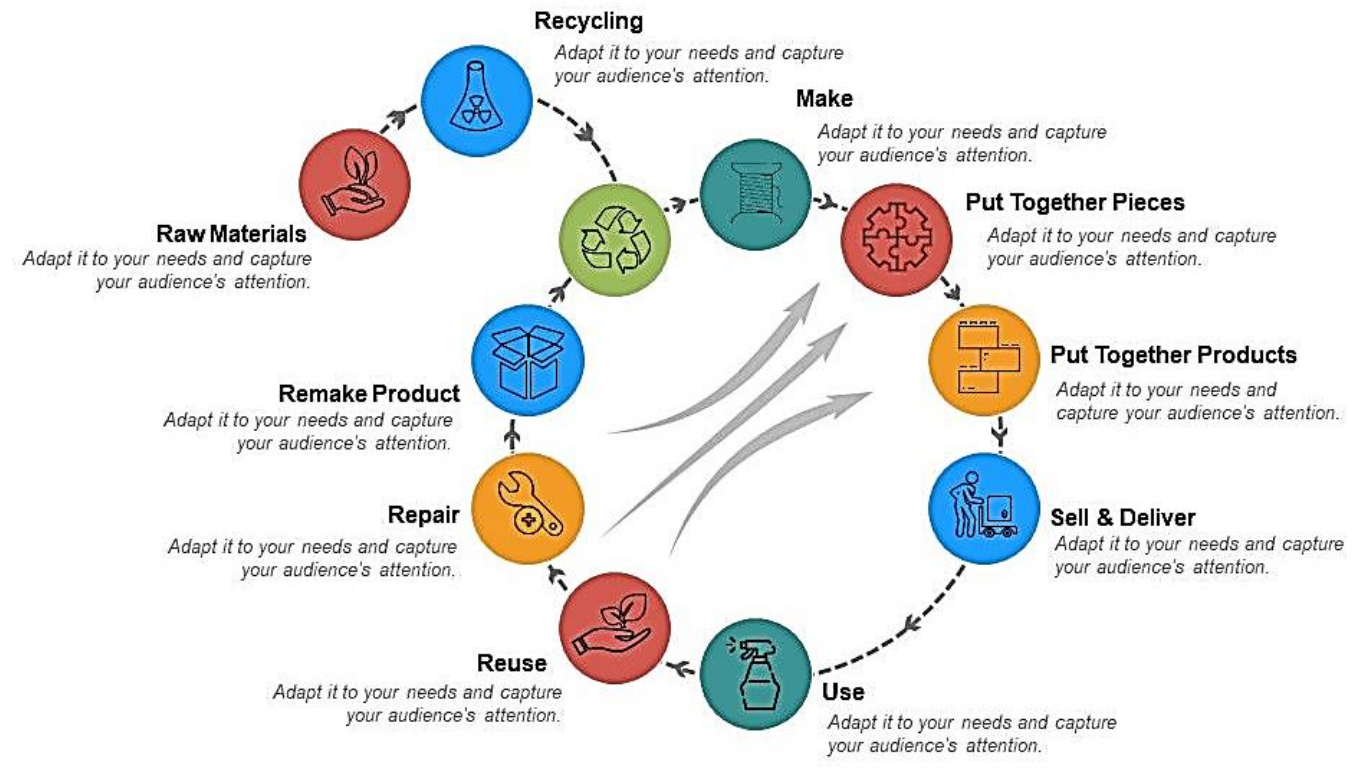

Source: https://www.slideteam.net/circular-economy-business-model-presentation-images.html.

From the literature, the concept of CE varied on its applicability. The CE as an approach focused on five aspects. 1) To regulate and minimize the resource utilization 2) Make optimal utilization of resources while in the cycle of usage 3) reintegrate the resources into the system 4) Technical Advancement in the existing business model promoting innovation 5) Promote sustainable economy. There is minimum assessment of CE applied to interweaved global supply chains. The concept of CE needs a value addition on understanding the established global production supply chains, established market conditions, the skill set of existing work force and baseline technical advancement.

The cutting-edge research was focused onto stabilizing and mainstreaming the concept of circular economy, that focus on "why, where and which" with minimal inscription on "how, when". Clearly defined operation principles aim for successful implementation of concept. Hannover (1991) defined his principles based on " $\mathrm{C} 2 \mathrm{C}$ ".

Figure 2: Hannover's principles of circular economy

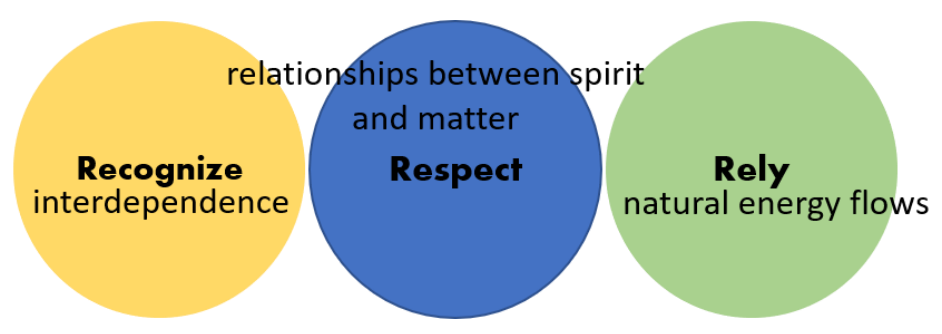

Source: author derived from literature review.

The operational principles of circular economy (Brais et al., 2019) should focus on adjusting the inputs and outputs governing the systems. Optimizing the system's performance for keeping the resources for maximum utility, for creating a closed loop should be the core principle. Knowledge sharing, innovation and educating the stakeholders should be guiding principles for governing agencies. 


\section{Dimensions of Circular economy}

With the low to mid income range categorisation, the developing nation's GNI Percapita ranges from $\$ 1,026$ to $\$ 4,035$. With diversified structural economics, no two developing nations are said to have recurrent characteristics. Developing nations are designated to have i) relatively low Percapita income ii) affordable labour force iii) rich natural resources iv) higher dependency on export income v) rural background with more $50 \%$ of population dependent on agriculture vi) unaccounted informal sector participation vii) unbalanced urbanisation viii) weak infrastructure ix) limited access to advanced country markets. Thus, for the successful implementation of CE concept, there should be advancements made in the following dimensions.

\subsection{Dimension I: Focus on "Sectors of economy"}

The aim of CE is to perceive the practical implementation of sustainable development, reducing the negative impacts caused through economic systems, bringing them under the coping capacities of biosphere (Brais et al., 2019). But the contemporary understanding of CE was focused onto industrial processes. The manufacturing sector was maximum explored under the theoretical influence of $\mathrm{C} 2 \mathrm{C}$, industrial ecology and blue economy. The primary sector of economy that includes the production of the raw materials, demands for prominence in the developing nations.

Figure 3: The potential sectors of bio-economy for next 20 years in developing nations

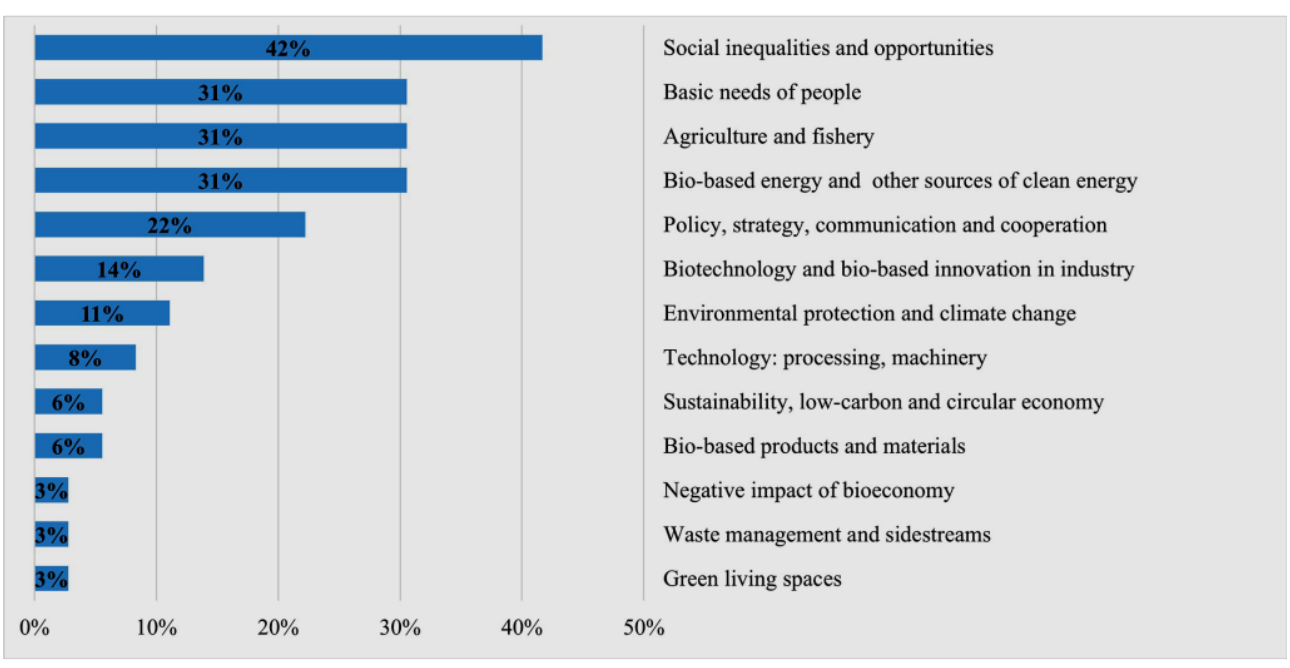

Source: Issa, 2019.

The concept of circular agro-food system focuses on closing the loop in three hierarchies i.e. at farmer, local and regional communities that would trigger the international trade (Cingiz.K et al.,2019). CE will be the response for marginalised agriculture sector in developing nations. Along with the existing progress that focus on reducing the waste, new fertilizers that balance the soil health, CE can scale up on innovation focusing the preservation of the produce, new affordable technologies for various farm size. The system must establish a balanced trade-off between both "production and supply side chains of primary sector". 


\subsection{Dimension II: Focus on "Existing occupational structure"}

Developing nations are categorised with major workforce occupied in primary sector, with shift to tertiary sector observed in recent years with a minimal percentage working in industrial sector. The trends indicate the fact of immense availability of low to medium skilled labour.

Figure 3: Occupational structure in India

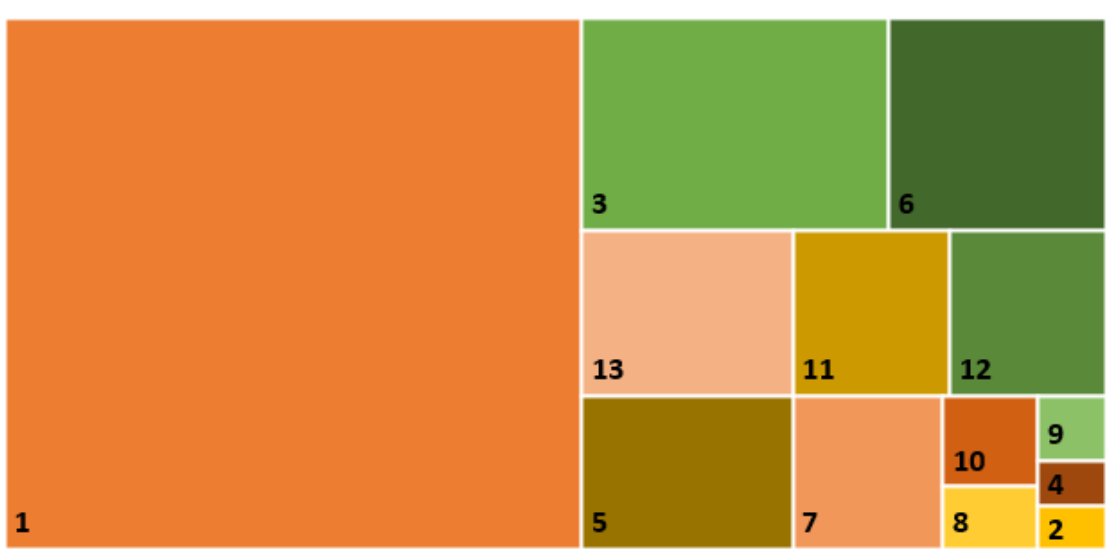

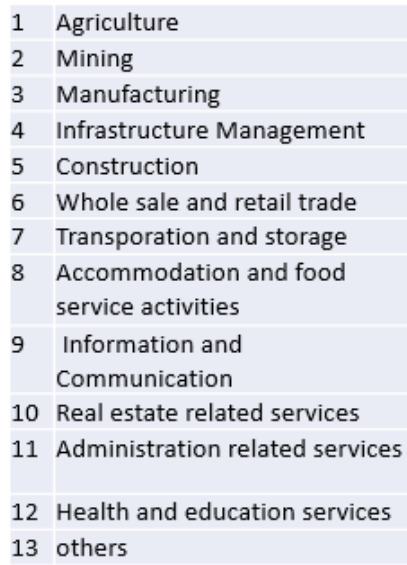

12 Health and education services 13 others

Source: census of India, 2011.

The studies predicted CE to have positive growth on employment creation. In brief, as the linear resource flows are replaced with circular activities, the employment in primary and moderately in secondary sector will be reduced or partially replaced with the new set of jobs. The new set of jobs requires new skill sets and to impart new education needs which would be a ticking task for developing nations to keep with the phase of CE (Willeghems, 2018).

\subsection{Dimension III: existing linkages of "Global value chains"}

The range of activities beginning with design, production, marketing and distribution of the commodities along with the various geographic interfaces can be termed as global value chains (GVC) (Gereffi and Fernandez-Stark, 2011). With the evolution of concept, the emphasis was laid on 'producer driven', 'consumer driven' chains and the focus onto 'networks' rather than chain was analysed (Gereffi 1994; Coe and Hess 2007). It's analysed that the level of fragmentation of production increased as the GVC's became more complex. The vertical specialization share (Hummels et al. 2001) which is used a key parameter for GVC participation index specifies that other than education and real estate, every commodity/ service is highly dependent on various national and international inputs for completion of the service. 


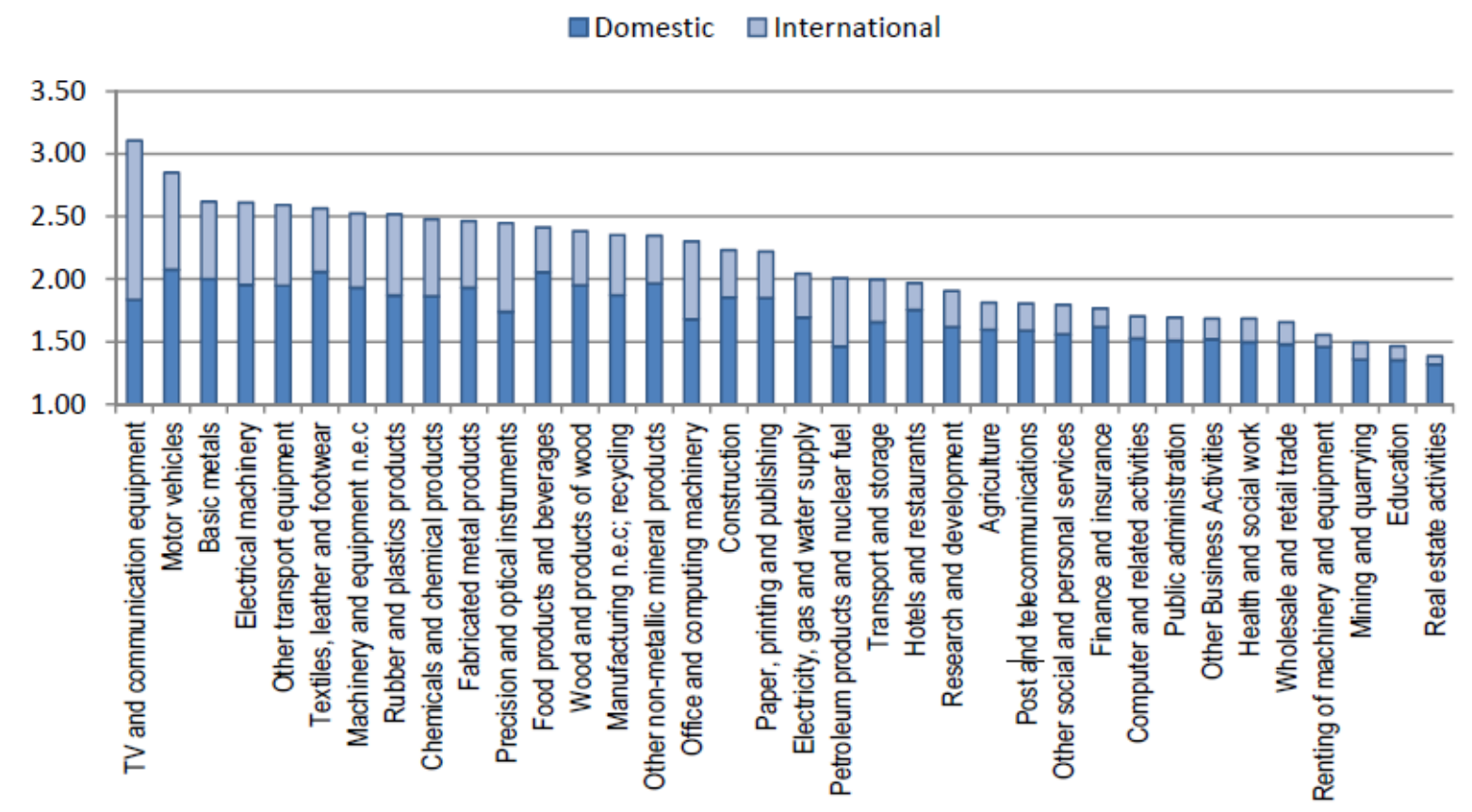

Source: Sébastien, 2012. *calculations based on the OECD ICIO model. The industries less than one are said to have no intermediates inputs.

The specialization of country based on its participation can be analysed using the extent of upstreamness" coined by Fally (2011), which indicates that greater the extent of upstreamness, larger is the possibility for country to be involved in production of a beginning of GVC. And most of the developing nation are said higher value of upstreamness. Thus, the CE concept while being designed to close the loop of the supply chain, needs to focus of networked geographic interactions that are taking place in GVC all across the globe. The cost of production which was the key principle behind the existing GVC should be a key principle factor behind CE innovations. Production inputs at local and regional level that are exported out to final stage of GCV, should be focused as separate micro-cycles for CE.

\subsection{Dimension IV: funds for "technological advancements"}

The technological advancement plays a vital role in achieving the integration of the economic systems, thus enabling the aim to close the loop. Technology not only binds the production and supply chain transformation, but will also contribute to transformation on consumers role (Sandoval et al., 2017). The upgradation in technology is linked to financial and operational costs. Though the upgradation happens for achieving the environmental deeds, the race for innovation has created a commercial business models that were having stand-alone benefits triggering the cost of production. This makes it difficult to achieve the closed loops as developing and under developed nations might fall behind taking the leap (Flyer, 2015). In the survey conducted by UNIDO (2018), to understand the challenges for implementation of $\mathrm{CE}$, most of responses list developing nations face limitation in institutional capacity, access to finance and technology.

Shifting to circular economy needs enormous investments in modified industrial process, smart infrastructure and technological innovations. Global reports state that the developing nations require $\$ 1$ trillion a year between 2020 and 2030 to bridge gaps for providing the basic infrastructure (Humphrey, 
2018). Unlike the cost-effective solution, high end technical innovations of CE might face market downfall risks (Preston et al., 2019). Though these nations are at verge of digital transformation, there is long way before they attain a financial stability.

\section{Perspective of Circularity in water and waste water reuse}

The phrase of "no product can end as direct waste" guides the circular economy concept. Just to present the discussion, progressions in water and waste water are discussed the framework to achieve CE involves actions of reduction of consumption, reclamation, reuse for the alterative uses, recovery of the water supplied, recovery of the characteristics and rethinking the existing system (Smol et al., 2020). CE can promote effective waster utilization by developing new design system for treatment-delivery and disposal, making the existing energy consumption greener, management of utilization between various fields preserving the local water cycles (Stuchtey, 2015).

The process is said to have higher economic and environmental benefits helping to achieve the targets set for SGD's. But the facts narrate that average amount of wastewater treatment reaches to 70 per cent in developed countries, whereas it is only 38 per cent in developed nations and as low as 28 per cent in least developed countries(Allaoui et al., 2015). Only 5 percentage of total consumption is reused. The following tables presents the results of An International Survey of current practice of water reuse.

Table 1:Types of wastewater reuse reported in different countries

\begin{tabular}{|c|c|c|c|c|c|c|c|c|c|}
\hline Aspect & Australia & Brazil & Canada & China & India & Italy & Nepal & $\begin{array}{l}\text { Singap } \\
\text { ore }\end{array}$ & $\begin{array}{l}\text { Zimbabw } \\
e\end{array}$ \\
\hline Agriculture & $x$ & $x$ & $x$ & $x$ & $x$ & $x$ & $x$ & $x$ & $x$ \\
\hline Municipal & $x$ & $x$ & $x$ & $x$ & & $x$ & & $x$ & \\
\hline \multicolumn{10}{|l|}{ Aquaculture } \\
\hline Potable & $x$ & & & $x$ & & & & & $x$ \\
\hline unplanned & & & & $x$ & & & & & \\
\hline indirect reuse & & & & $x$ & & & & & \\
\hline $\begin{array}{l}\text { Groundwater } \\
\text { recharge }\end{array}$ & $x$ & & & $x$ & $x$ & $x$ & & & \\
\hline Industrial & $x$ & & & $x$ & & $x$ & & $x$ & \\
\hline Environment & $x$ & & $x$ & $x$ & & & & & $x$ \\
\hline Planned & $x$ & $x$ & & & & $x$ & & $x$ & $x$ \\
\hline Non-planned & & $x$ & & $x$ & $x$ & $x$ & $x$ & & $x$ \\
\hline Future plans & $x$ & $x$ & & $x$ & $x$ & $x$ & & $x$ & $x$ \\
\hline Desalination & & & & & $x$ & $x$ & & $x$ & \\
\hline Other type & $x$ & & & $x$ & & & & & \\
\hline
\end{tabular}

Source: Jimenez, 2015. 
The observations state the most of developed countries have the technology, system to achieve the circularity but the efficiency of the system is undetermined. A very few of the least developed and developing nations has enough finance and technology to focus towards reclaiming the drops of water. Most of the countries do not have the adequate legislation in place to guide the development of required actions. Thus, there is huge gap in socio-technical systems for developing and least developed nations to advance in CE.

Though there are existing technological system in place, the efficiency and accessibility of system are conditional clause as none of the country has crosses the reuse/extraction of water percentage more than 35. Thus, there is need for the capacity's upgradations for all the nations to achieve the maximum functionality and reach the goals of CE.

Figure 5: Comparision of Adoptability to water reuse in various countries
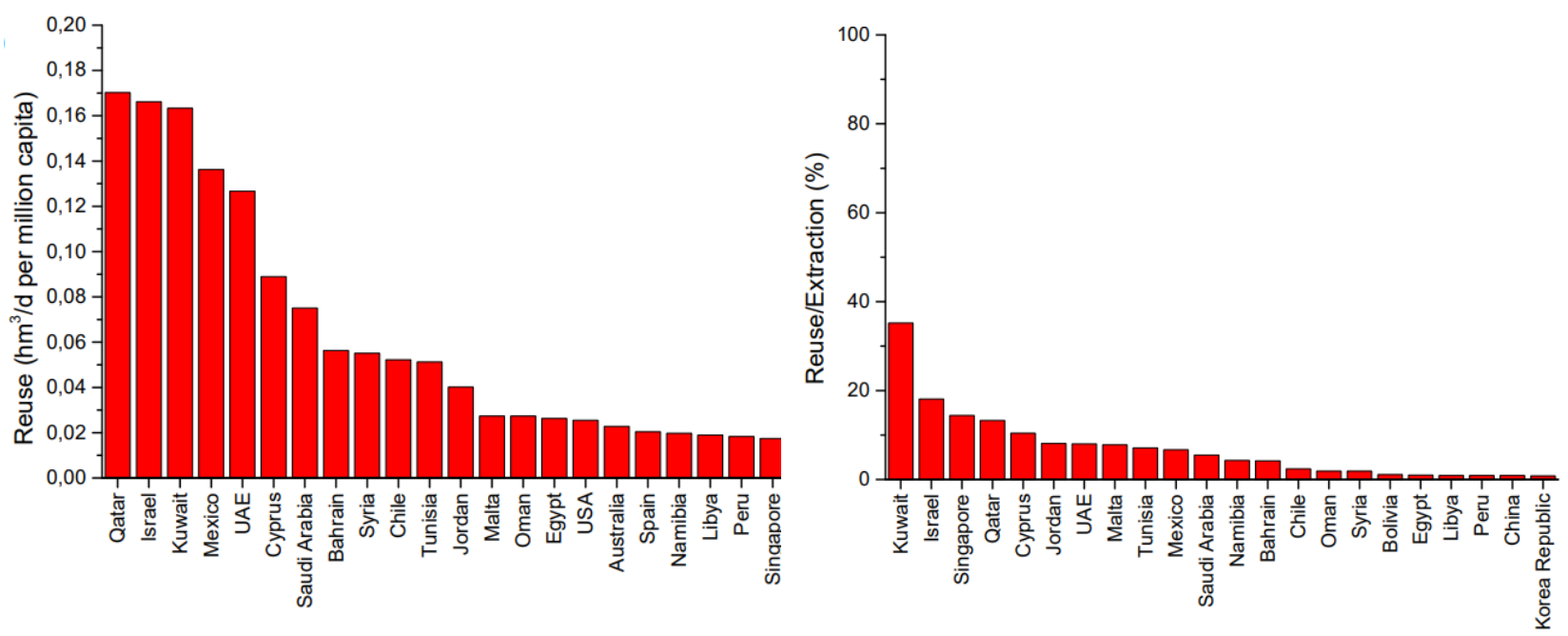

Source: Jiménez, 2008.

\section{Conclusion}

CE is an emerging concept with scope to balance the development with environment coping capacity. Varying growth dynamics impact the progression of CE in many divergent directions. Developing nations holding the maximum potential to change the face of $C E$, the concept demands for focus on new dimensions for the applicability of the concept. There is need to increase the focus of CE not only on research related to balance the economy and environment dimensions, but also to take into consideration the social dimension.

The concept of CE needs momentum on political will to align the development policies promoting circularity. There is a need to promote the market management for circular Goods and products, achieving the shift consumer demand. The concept has to focus on integrating the production and supply systems uniquely and collectively from hamlet to global scales. Research to define the role of different stakeholders for establishing CE system in place should be concentrated.

World cities are the home for growth dynamics where the experimentation of new concepts needs local adaptability. Adopting to a circular lifestyle will takes different plus depending on the economic stability of the nation, thus in the initial years "voice for the local" will yield positive results. 
Figure 6: Proposed dimensions of circular economy

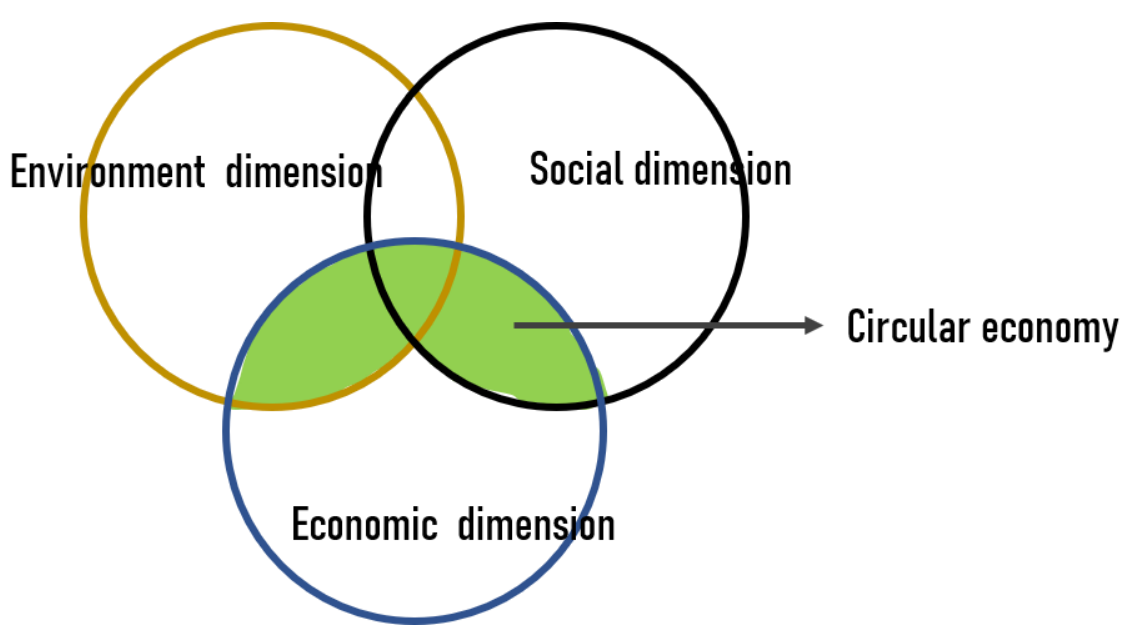

Source: author derived from literature review.

\section{References}

- Allaoui, M. Schmitz, T. Campbell, D. and de la Porte, A.C. (2015), “Good practices for regulating wastewater treatment: legislation, policies and standards", available at:

http://unep.org/gpa/documents/publications/GoodPracticesforRegulatingWastewater.pdf, accessed on $27^{\text {th }}$ July, 2020.

- Benyus, Janine M. 1(997). Biomimicry: innovation inspired by nature. New York: Morrow.

- $\quad$ Brais S.E, Emilio.F, Gonzalo.M.M,David.S.N, (2019), Operational principles of circular economy for sustainable development: Linking theory and practice, journal on cleaner production 214 P.952961

- Coe, N. M. and M. Hess (2007), “Global production networks: debates and challenges", paper prepared for the GPERG workshop, University of Manchester.

- Cingiz.k , Wesseler.j (2019) Opportunities and the Policy Challenges to the Circular Agri-food System: Circular Approach and the Sustainability of the Agro-food System - Closing Resource Loops to Improve Sustainability, OECD,Paris.

- Ellen MacArthur Foundation, (2016) Circular Economy in India: Rethinking growth for long-term prosperity, , http://www.ellenmacarthurfoundation.org/publications/.

- Flyer.M,(2015), "The Circular Economy: A perspective from the technology sector" Available at: www.techuk.org/circulareconomy (Accessed: 16 July, 2020).

- Government of People's Republic of China, (2008) Circular Economy Promotion Law of the People's Republic of China. Adopted at the fourth session of the Standing Committee of the 11th National People's Congress on August 29, 2008.

- Genovese, A.A. Acquaye, A. Figueroa, S.L. Koh, (2017), Sustainable supply chain management and the transition towards a circular economy: evidence and some applications Omega, 66 p. 344357.

- Gereffi, G. and K. Fernandez-Stark (2011). "Global Value Chain Analysis: A Primer", Center on Globalization, Governance \& Competitiveness (CGGC), Duke University, North Carolina, USA. 
- Gereffi, G. (1994), "The organization of buyer-driven global commodity chains: how US retailers shape overseas production networks". In: G. Gereffi and M. Korzeniewicz (eds), Commodity Chains and Global Capitalism, Westport, CT: Praeger, 95-122.

- Hawken, Paul. (2000). Natural capitalism: creating the next industrial revolution. Boston: Little, Brown and Co

- Heshmati.A, (2015), A Review of the Circular Economy and its Implementation. IZA Discussion Paper No. 9611.

- Hummels, D., J. Ishii and K.-M. Yi (2001), "The nature and growth of vertical specialization in world trade", Journal of International Economics 54(1), 75-96.

- Humphrey, C. (2018), Channelling private investment to infrastructure: What can multilateral development banks realistically do?, ODI Workingpaper 534, London: Overseas Development Institute, https://www.odi.org/publications/11119-channelling-private-investmentinfrastructurewhat-can-multilateral-development-banks-realistically (Accessed: 16 July, 2020).

- Issa I, Delbru“ck S, Hamm U (2019) Bioeconomy from experts' perspectives - Results of a global expert survey. PLoS ONE 14(5):e0215917. https://doi.org/10.1371/journal. pone.0215917.

- Jimenez , B., \& Asano, T. (2015). Water Reuse: An International Survey of current practice, issues and needs. Water Intelligence Online, 7(0), 9781780401881-9781780401881. doi:10.2166/9781780401881.

- Jiménez, B.; Asano, T. (2008). Water reclamation and reuse around the world. In Water ReuseAn International Survey of Current Practice, Issues and Needs; IWA Publishing: London, UK.

- James J. Sullivan \& H. F. Arias, (1972) Concepts and Principles for Environmental Economics, 2 B.C. Envtl. Aff. L. Rev. 597, http://lawdigitalcommons.bc.edu/ealr/vol2/iss3/8.

- Kalmykova.Y, Sadagopan.M, Rasado.L (2018), Circular economy - From review of theories and practices to development of implementation tools, resource, conservation and recycling, volume 135, p.190-201.

- McDonough, W., \& Braungart, M. (2002). Cradle to cradle: Remaking the way we make things. London: Vintage.

- Mishan, E. J. (1967), THE COST OF ECONOMIC GROWTH New York: Praeger, 53.

- Preston.F, Lehna.J,Wellesley.L,(2019)," An Inclusive Circular Economy Priorities for Developing Countries", The Royal Institute of International Affairs, Chatham House, ISBN 9781784133382.

- Stahel W.R. (2008) The Performance Economy: Business Models for the Functional Service Economy. In: Misra K.B. (eds) Handbook of Performability Engineering. Springer, London

- Sébastien.M,(2012) MAPPING GLOBAL VALUE CHAINS, The OECD Conference Centre, Paris.

- Sandoval.P.V, Jaca.C, Ormazabal.M (2017)," Towards a consensus on the circular economy", Journal of Cleaner Production 179(1),605-615.

- Smol, M., Adam, C. \& Preisner, M. (2020). Circular economy model framework in the European water and wastewater sector. J Mater Cycles Waste Manag 22, 682-697 https://doi.org/10.1007/s10163-019-00960-z

- Stuchtey.M (2015), Rethinking the water cycle, available at https://www.mckinsey.com/businessfunctions/sustainability/our-insights/rethinking-the-water-cycle, accessed on $27^{\text {th }}$ July, 2020. 
- V.K.Smith, (2002), Environmental Economics, International Encyclopedia of the Social \& Behavioural Sciences, pg: 4611-4617.

- W.R. Stahel, (2013), Policy for material efficiency-sustainable taxation as a departure from the throwaway society. philosophical transactions of the royal society a: mathematical, Phys. Eng. Sci., p. 371

- Willeghems.G, Bachus.K,(2018), Employment impact of the transition to a circular economy: literature study, Department Of Economy Science \& Innovation, Circular Economy (CE) Policy Research Center, Belgium.

- Y. Geng, J. Sarkis, S. Ulgiati, P. Zhang (2013), Measuring China's circular economy Science, 339 (6127) pp. 1526-1527. 